\title{
COMPARISON OF SOIL PROPERTIES OF AN ADJACENT CLAY MINE SPOIL, A MINING SITE RECLAIMED WITH STONE PINE (Pinus pinea L.) PLANTATION AND A NATURAL FOREST
}

\author{
KARATEPE, Y. ${ }^{{ }^{*}}-$ KÜLCÜOĞLU, C. ${ }^{2}-$ MAKINECI, E. $^{3}$ \\ ${ }^{1}$ Isparta University of Applied Sciences - Faculty of Forestry, Soil Science and Ecology \\ Department, Isparta, Turkey \\ (phone: +90-246-214-6512; fax: +90-246-214-6599) \\ ${ }^{2}$ Isparta University of Applied Sciences - The Institute of Graduate Education, Forest \\ Engineering Department, Isparta, Turkey \\ (phone: +90-543-829-7840; fax: +90-246-214-6599) \\ ${ }^{3}$ Istanbul University - Cerrahpaşa, Faculty of Forestry, Soil Science and Ecology Department, \\ Bahceköy, Sartyer, Istanbul, Turkey \\ (phone: +90-212-338-2400; fax: +90-212-226-1113) \\ ${ }^{*}$ Corresponding author \\ e-mail: yasinkaratepe@isparta.edu.tr; phone: +90-246-214-6512; fax: +90-246-214-6599 \\ (Received $18^{\text {th }}$ May 2020; accepted $13^{\text {th }}$ Aug 2020)
}

\begin{abstract}
The purpose of this study was to compare the soil properties of an adjacent natural forest, clay mine spoil and mine site reclaimed with Stone pine (Pinus pinea L.). Bulk density, sand, silt, clay, pH, electrical conductivity (EC), nitrogen $(\mathrm{N})$, carbon $(\mathrm{C})$ and $\mathrm{C} / \mathrm{N}$ ratios of soil samples taken from three different soil depths $(0-5,5-15$ and 15-30 cm) were determined and compared. Furthermore, the mass, $\mathrm{N}$ and $\mathrm{C}$ contents and $\mathrm{C} / \mathrm{N}$ ratios of the forest floor were determined in the Stone pine plantation and natural forest. Almost 24 years after the establishment, 6.79 ton/ha forest floor mass was found in the Stone pine plantation, while it was found to contain 2.71 ton $\mathrm{C} / \mathrm{ha}$ and 0.04 ton N/ha, which were significantly lower than those in the natural forest. In general, with some exceptions (EC in $0-5$ and 5-15 cm, and bulk density in $15-30 \mathrm{~cm}$ ), there were significant differences on the soil properties. Sand and clay contents varied substantially depending on the material and mixture. The soil $\mathrm{C}(1.5-2.1 \%), \mathrm{N}(0.05-0.06 \%)$ and $\mathrm{pH}$ (5.34-5.69) in the Stone pine plantation significantly increased. Despite these properties, this shows that rehabilitation with plantation will take a much longer time compared to the natural forest area.
\end{abstract}

Keywords: afforestation, carbon, nitrogen, $\mathrm{pH}$, restoration

\section{Introduction}

Mine production and mining operations have been exponentially increasing across the entire world. Open pit sites in particular lead to drastic degradation of soil and land. Mining activities have disruptive effects on the ecosystem, and affect the physical, chemical and biological soil properties of mining sites. First the plant cover is destroyed, then fertile top soil layers are removed from the site through major excavations, and the soil is compacted and destroyed due to the sue of heavy duty vehicles to open large pits created as a result of deep slopes. Moreover, soil organic matter disappears substantially and the material becomes too poor in terms of plant nutrients including primarily nitrogen. This is especially important for the restoration of sites after mining operations (Shrestha and Lal, 2011; Frouz et al., 2015; Gu et al., 2019). 
Most of the mineral and natural resources are located in forestlands around the globe (Burton and Macdonald, 2011). Mineral extraction and processing in forestlands lead to their destruction at a large extent (Burton and Macdonald, 2011) and turning forestlands into mining sites lead to extremely harmful changes in the ecosystem and soil (Ahirwal and Maiti, 2016). Such practices increase the pressure on forest areas (Gençay et al., 2018).

It is essential to rapidly restore severely destroyed areas after mining activities (Frouz et al., 2015). Plantation is the most commonly used method to restore abandoned mining sites. However, mining tailings-spoils that have very poor physical, chemical and biological properties and levelled mine soils usually inhibit plant existence and growth (Asensio et al., 2013; Rodríguez-Vila et al., 2016). The use of forest tree species among the plant species is a common way while it requires selecting the appropriate species (Mukhopadhyay et al., 2013).

Moreover, different tree species have different restorative properties (Mukhopadhyay et al., 2013). Therefore, it is crucial to determine the improvements and changing properties after establishing plantations for the restoration and reclamation of mining sites. Comparison with adjacent control sites is a preferred way to demonstrate the rehabilitative power of the treatments conducted (Shrestha and Lal, 2011; Liu et al., 2017; Gu et al., 2019). There are several studies regarding the rehabilitative features of tree species for mine sites (Juwarkar et al., 2010; Mukhopadhyay and Maiti, 2011; Gu et al., 2019).

The main physical and chemical soil properties played a determining role in these studies. Bulk density and soil texture type (sand, silt and clay contents), which are among the main soil properties identified, have an important impact on hydro-dynamic properties of the soil, are also important parts of soil quality parameters (Kantarc1, 2000; Yuan et al., 2017) and important for plant development (Asensio et al., 2013). In addition to organic soil and forest floor mass, carbon and nitrogen contents of forest floor (Walmsley et al., 2019) in the restored mining sites, presence of soil carbon and nitrogen are important criteria for biological activity and soil fertility (Frouz et al., 2013; Ahirwal and Maiti, 2016). Besides, soil acidity $(\mathrm{pH})$ and electrical conductivity (EC) have an impact in many soil chemical processes while they also have biological effects (Mukhopadhyay et al., 2013; Mosseler and Major, 2017).

This study was conducted in order to determine the change in soil properties caused by clay mining activity and the effect of Stone pine (Pinus pinea L.) plantations in mine spoils after the termination of clay mining. To this end, the study was designed to compare the soil properties at different depths $(0-5,5-15$ and $15-30 \mathrm{~cm})$ and the existing forest floor of three different sites, which included the abandoned clay mine spoil, the adjacent clay mine reclaimed with 24-year old Stone pine (Pinus pinea L.) plantation and the adjacent natural forest.

\section{Material and method}

\section{Research area}

The research area was located in Şile-Istanbul in the northwest of Turkey (N41 $08^{\prime} 07^{\prime \prime}-41^{\circ} 08^{\prime} 16^{\prime \prime}$; E29 $\left.27^{\prime} 11^{\prime \prime}-29^{\circ} 27^{\prime} 21^{\prime \prime}\right)$. The clay mine site studied in the research and its surroundings are in the south of Istanbul-Şile Highway, while it is $53 \mathrm{~km}$ to Istanbul and $17 \mathrm{~km}$ to Şile. The distance of the research area to the sea (Black Sea) is around $6.5 \mathrm{~km}$ in air distance. As regards the topography of the research area, it is situated on peneplain, its elevation is $115-150 \mathrm{~m}$ (Fig. 1). 


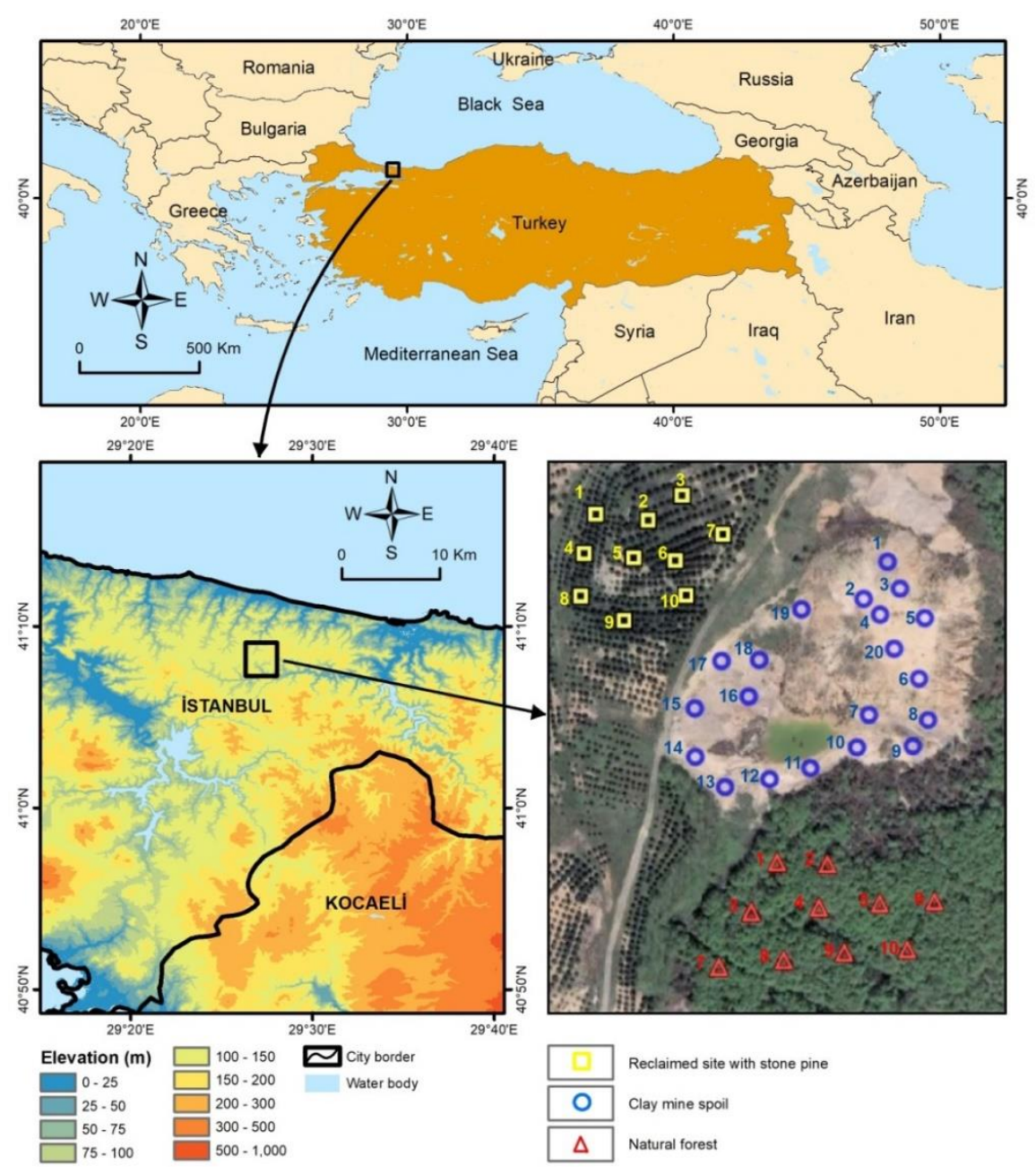

Figure 1. Location of study area

As for its geological structure, Neogene sediments are common in the site, while mainly sandy layers are located on the surface and clay is found in the lower layers (Ertek et al., 1998; Demir et al., 2016). In the geological literature of Turkey, Şile (Istanbul) Neogene Basin is referred to as a storage of natural industrial raw materials, which supplies $90 \%$ of industrial clay demands in Turkey (Sezer, 2006). Brown forest soil is the common soil type in the natural forests where land degradation did not occur.

Transition climate between the Mediterranean climate and Black Sea Climate is dominant in the research area. According to the data of Şile Meteorology Station, its mean annual precipitation is $929 \mathrm{~mm}$. Its mean annual temperature is $13.6{ }^{\circ} \mathrm{C}$, mean monthly minimum temperature is $-3.8{ }^{\circ} \mathrm{C}$ in February, mean monthly maximum temperature is $31.8{ }^{\circ} \mathrm{C}$ in September and relative humidity is $80.5 \%$ (Sezer, 2006). The natural forest from which sample plots were selected is an oak coppice forest and includes mainly Quercus petraea as the dominant species, while Fagus orientalis, Castenae sativa and Sorbus torminalis are the other tree species included in the mixture in some of the sample plots. In addition to these species, Quercus robur, Quercus frainetto, Alnus glutinosa, Acer campestre, Fraxinus excelsior, Carpinus betulus, Tilia tomentosa, Populus tremula, Corylus avellana, Cornus mas, Mespilus germanica, 
Buxus sempervirens are the other tree or shrub species distributed in the forests in this region (Dönmez, 1979).

\section{Sampling and methods}

This study was conducted to determine the effect of Stone pine (Pinus pinea L.) plantation introduced for the rehabilitation of the clay mine spoils after clay extraction operations on soil properties in three different adjacent sites including 1) the clay mine spoil 2) clay mine site reclaimed with Stone pine plantation and 3) natural forest. The Stone pine plantation was established by direct planting method without any rehabilitation or laying topsoil almost 24 years ago (determined according to the annual growth ring samples taken from the trees) on top of the mining tailings-spoils. The huge pits in the clay mine tailings site were filled and the site was leveled and abandoned. In the adjacent natural forest land, Quercus petraea of coppice origin which protects its natural structure is the dominant species. Adjacent sites were selected for common site characteristics (Fig. 2).
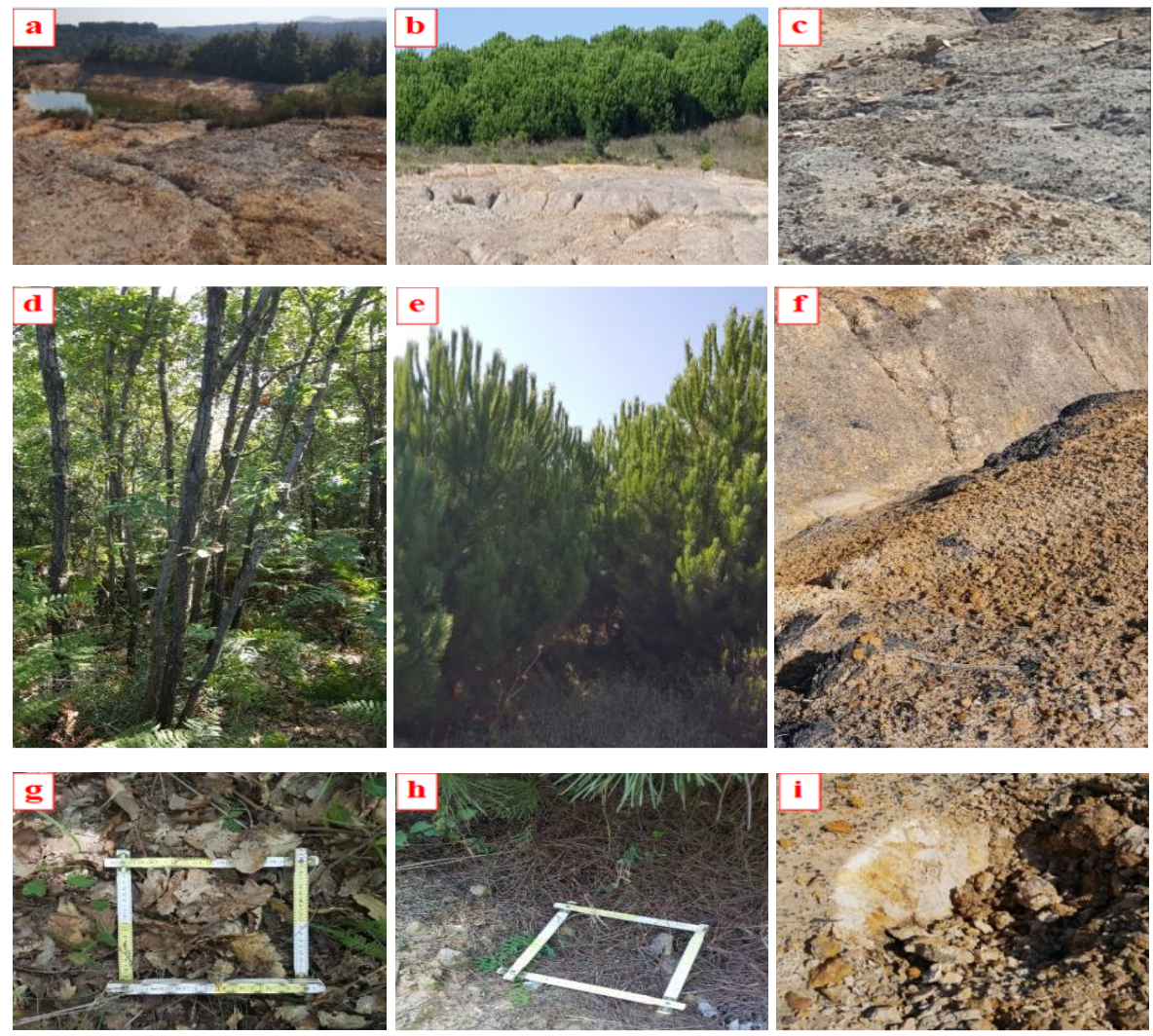

Figure 2. Pictures from research sites, a) transect view on clay mine spoil and natural forest, $b$ ) transect view on clay mine spoil and Stone pine plantation, c) a part from clay mine spoil, d) natural forest, e) Stone pine plantation, $f$ ) different surface layers of clay mine spoil, $g$ ) forest floor of natural forest, $h$ ) forest floor of Stone pine plantation, i) heterogeneity structure of clay mine spoil

The number, diameter $(\mathrm{dbh})$ and height of the trees were determined in 10 sample plots of $5 \times 5=25 \mathrm{~m}^{2}$ in the natural forest and of $4 \times 3=12 \mathrm{~m}^{2}$ from the Stone pine plantation because plantation has same planting distance $(4 \times 3 \mathrm{~m})$. The density, average 
diameter (dbh) and height of the trees in these sites are presented in Table 1. The mean age of the Stone pine plantation was found to be 24 years according to the annual ring samples collected from a tree in each sample plot of the plantation.

Table 1. Density, average diameter (dbh) and height of trees on sample plots

\begin{tabular}{c|c|c}
\hline Characteristics & Natural forest & Stone pine plantation \\
\hline Tree number $(\mathrm{ha})$ & $3760 \pm 1053$ & $3250 \pm 264$ \\
Diameter $(\mathrm{dbh})(\mathrm{cm})$ & $8.08 \pm 1.39$ & $9.39 \pm 1.18$ \\
Height $(\mathrm{m})$ & $6.98 \pm 1.09$ & $4.45 \pm 0.63$ \\
\hline
\end{tabular}

\pm standard deviation, Stone pine (Pinus pinea L.) plantation age: $24 \pm 2$, main species in natural forest is oak (Quercus petraea L.)

The soil samples were collected from 10 plots in the natural forest and Stone pine plantation and 20 plots in the clay mine spoils site (Table 2). We selected more sampling points from mine spoils site to represent the area because the mine site is more heterogeneous (Figs. 1-2). Soil samples for bulk density were collected from these three sites at depths of $0-5 \mathrm{~cm}, 5-15$ and $15-30 \mathrm{~cm}$ in the selected plots that could represent the overall site during the field studies. Moreover, forest floor samples were collected from areas of $1 / 4 \mathrm{~m}^{2}$ in from each sample plot in the natural forest and Stone pine plantation with 5 repetitions (Fig. 2). As the forest floor did not cover the entire soil surface contrary to the one in the natural forest, the percentage of forest floor coverage was determined in plantation. This value was found to be $51.3 \%$ on average, while the coverage percentage of each site was averaged to their total forest floor mass.

Table 2. The coordinates of sample plots

\begin{tabular}{|c|c|c|c|c|c|c|c|}
\hline Site & $\begin{array}{c}\text { Point } \\
\text { number }\end{array}$ & Longitude (E) & $\begin{array}{c}\text { Latitude } \\
(\mathbf{N})\end{array}$ & Site & $\begin{array}{c}\text { Point } \\
\text { number }\end{array}$ & Longitude (E) & $\begin{array}{c}\text { Latitude } \\
\text { (N) }\end{array}$ \\
\hline \multirow{10}{*}{$\begin{array}{l}\text { Stone pine } \\
\text { plantation }\end{array}$} & 1 & $29^{\circ} 27^{\prime} 12.33^{\prime \prime}$ & $41^{\circ} 08^{\prime} 14.75^{\prime \prime}$ & \multirow{20}{*}{$\begin{array}{l}\text { Clay } \\
\text { mine } \\
\text { spoil }\end{array}$} & 1 & $29^{\circ} 27^{\prime} 18.16^{\prime \prime}$ & $41^{\circ} 08^{\prime} 14.31^{\prime \prime}$ \\
\hline & 2 & $29^{\circ} 27^{\prime} 13.39^{\prime \prime}$ & $41^{\circ} 08^{\prime} 14.70^{\prime \prime}$ & & 2 & $29^{\circ} 27^{\prime} 17.72^{\prime \prime}$ & $41^{\circ} 08^{\prime} 13.72^{\prime \prime}$ \\
\hline & 3 & $29^{\circ} 27^{\prime} 14.04^{\prime \prime}$ & $41^{\circ} 08^{\prime} 15.10^{\prime \prime}$ & & 3 & $29^{\circ} 2718.44^{\prime \prime}$ & $41^{\circ} 08^{\prime} 13.92^{\prime \prime}$ \\
\hline & 4 & $29^{\circ} 27^{\prime} 12.13^{\prime \prime}$ & $41^{\circ} 08^{\prime} 14.15^{\prime \prime}$ & & 4 & $29^{\circ} 27^{\prime} 18.07^{\prime \prime}$ & $41^{\circ} 08^{\prime} 13.50^{\prime \prime}$ \\
\hline & 5 & $29^{\circ} 27^{\prime} 13.13^{\prime \prime}$ & $41^{\circ} 08^{\prime} 14.13^{\prime \prime}$ & & 5 & $29^{\circ} 27^{\prime} 18.97^{\prime \prime}$ & $41^{\circ} 08^{\prime} 13.50^{\prime \prime}$ \\
\hline & 6 & $29^{\circ} 27^{\prime} 13.97^{\prime \prime}$ & $41^{\circ} 08^{\prime} 14.12^{\prime \prime}$ & & 6 & $29^{\circ} 27^{\prime} 18.92^{\prime \prime}$ & $41^{\circ} 08^{\prime} 12.57^{\prime \prime}$ \\
\hline & 7 & $29^{\circ} 27^{\prime} 14.89^{\prime \prime}$ & $41^{\circ} 08^{\prime} 14.56^{\prime \prime}$ & & 7 & $29^{\circ} 27^{\prime} 17.95^{\prime \prime}$ & $41^{\circ} 08^{\prime} 11.97^{\prime \prime}$ \\
\hline & 8 & $29^{\circ} 27^{\prime} 12.09^{\prime \prime}$ & $41^{\circ} 08^{\prime} 13.52^{\prime \prime}$ & & 8 & $29^{\circ} 27^{\prime} 19.15^{\prime \prime}$ & $41^{\circ} 08^{\prime} 11.95^{\prime \prime}$ \\
\hline & 9 & $29^{\circ} 27^{\prime} 12.99^{\prime \prime}$ & $41^{\circ} 08^{\prime} 13.19^{\prime \prime}$ & & 9 & $29^{\circ} 27^{\prime} 18.87^{\prime \prime}$ & $41^{\circ} 08^{\prime} 11.53^{\prime \prime}$ \\
\hline & 10 & $29^{\circ} 27^{\prime} 14.21^{\prime \prime}$ & $41^{\circ} 08^{\prime} 13.62^{\prime \prime}$ & & 10 & $29^{\circ} 27^{\prime} 17.74^{\prime \prime}$ & $41^{\circ} 08^{\prime} 11.45^{\prime \prime}$ \\
\hline \multirow{10}{*}{$\begin{array}{c}\text { Natural } \\
\text { forest }\end{array}$} & 1 & $29^{\circ} 27^{\prime} 16.23^{\prime \prime}$ & $41^{\circ} 08^{\prime} 09.62^{\prime \prime}$ & & 11 & $29^{\circ} 27^{\prime} 16.81^{\prime \prime}$ & $41^{\circ} 08^{\prime} 11.10^{\prime \prime}$ \\
\hline & 2 & $29^{\circ} 27^{\prime} 17.25^{\prime \prime}$ & $41^{\circ} 08^{\prime} 09.63^{\prime \prime}$ & & 12 & $29^{\circ} 27^{\prime} 16.01^{\prime \prime}$ & $41^{\circ} 08^{\prime} 10.89^{\prime \prime}$ \\
\hline & 3 & $29^{\circ} 27^{\prime} 15.75^{\prime \prime}$ & $41^{\circ} 08^{\prime} 08.82^{\prime \prime}$ & & 13 & $29^{\circ} 27^{\prime} 15.12^{\prime \prime}$ & $41^{\circ} 08^{\prime} 10.73^{\prime \prime}$ \\
\hline & 4 & $29^{\circ} 27^{\prime} 17.12^{\prime \prime}$ & $41^{\circ} 08^{\prime} 08.93^{\prime \prime}$ & & 14 & $29^{\circ} 27^{\prime} 14.51^{\prime \prime}$ & $41^{\circ} 08^{\prime} 11.17^{\prime \prime}$ \\
\hline & 5 & $29^{\circ} 27^{\prime} 18.36^{\prime \prime}$ & $41^{\circ} 08^{\prime} 09.03^{\prime \prime}$ & & 15 & $29^{\circ} 27^{\prime} 14.46^{\prime \prime}$ & $41^{\circ} 08^{\prime} 11.90^{\prime \prime}$ \\
\hline & 6 & $29^{\circ} 27^{\prime} 19.50^{\prime \prime}$ & $41^{\circ} 08^{\prime} 09.10^{\prime \prime}$ & & 16 & $29^{\circ} 27^{\prime} 15.53^{\prime \prime}$ & $41^{\circ} 08^{\prime} 12.13^{\prime \prime}$ \\
\hline & 7 & $29^{\circ} 27^{\prime} 15.15^{\prime \prime}$ & $41^{\circ} 08^{\prime} 07.94^{\prime \prime}$ & & 17 & $29^{\circ} 27^{\prime} 14.96^{\prime \prime}$ & $41^{\circ} 08^{\prime} 12.64^{\prime \prime}$ \\
\hline & 8 & $29^{\circ} 27^{\prime} 16.45^{\prime \prime}$ & $41^{\circ} 08^{\prime} 08.08^{\prime \prime}$ & & 18 & $29^{\circ} 27^{\prime} 15.71^{\prime \prime}$ & $41^{\circ} 08^{\prime} 12.69^{\prime \prime}$ \\
\hline & 9 & $29^{\circ} 27^{\prime} 17.68^{\prime \prime}$ & $41^{\circ} 08^{\prime} 08.23^{\prime \prime}$ & & 19 & $29^{\circ} 27^{\prime} 16.50^{\prime \prime}$ & $41^{\circ} 08^{\prime} 13.49^{\prime \prime}$ \\
\hline & 10 & $29^{\circ} 27^{\prime} 18.98^{\prime \prime}$ & $41^{\circ} 08^{\prime} 08.31^{\prime \prime}$ & & 20 & $29^{\circ} 27^{\prime} 18.39^{\prime \prime}$ & $41^{\circ} 08^{\prime} 13.00^{\prime \prime}$ \\
\hline
\end{tabular}


The soil samples collected from the area for bulk density were air dried, ground in a mortar, screened through a $2-\mathrm{mm}$ sieve and fine soil fraction $(<2 \mathrm{~mm})$ and stones were removed. The samples were oven dried at $105^{\circ} \mathrm{C}$ till constant weight and their weight in unit bulk was found. Then, based on these weight values, the amount of fine soil $(<2$ $\mathrm{mm})$ per hectare was calculated for each depth layer $(0-5,5-15$ and $15-30 \mathrm{~cm})$. The particle diameter (sand, silt and clay contents) in the soil samples prepared for analysis was analyzed with Bouyoucos hydrometer, soil reaction $(\mathrm{pH})$ was analyzed with $\mathrm{pH}$ meter containing glass electrode in a solution mixed with distilled water at a ratio of 1/2.5; salinity (electrical conductivity, EC) with salinity meter in a solution mixed with distilled water at a ratio of $1 / 5$; organic carbon with Walkley-Black wet oxidation method and the total nitrogen with semi-micro Kjeldahl method (Karaöz, 1989a,b). To prepare the forest floor samples for analysis, they were dried at $70 \mathrm{C}^{\circ}$ till constant weight. The dried samples were weighed and the amount of forest floor mass in areas of $1 / 4 \mathrm{~m}^{2}$ was calculated. Based on these values, forest floor masses per hectare was found. Then, the forest floor samples were ground to be prepared for analysis while their carbon and nitrogen contents were determined with Leco Truspec $2000 \mathrm{CN}$ analysis device by dry combustion method.

Amounts per hectare were determined on the basis of the carbon and nitrogen concentrations of forest floor and soil found through analyses. Then the similarities and differences between the sites were compared with Analysis of Variance (ANOVA) for each data obtained through analysis results and calculations while the features found to be significant according to the analysis of variance were evaluated with Duncan posthoc test due to inequality of the numbers of sample plots and sampling points among sites. As there was no forest floor on the mine spoil, the forest floor characteristics of the Stone pine plantation and the natural forest were compared with 2-independent samples t test. IBM SPSS STATISTIC 20 for Windows computer software package was used for the statistical evaluation of the data. Base ANOVA results were presented in Appendix Tables 1-3.

\section{Results}

\section{Forest floor characteristics}

The mass of forest floor in the Stone pine plantation (6.79 ton/ha) was much lower than the one in the natural forest $(28.07 \mathrm{ton} / \mathrm{h})$. The carbon concentration of the forest floor was almost the same in both sites (around 40\%), while the nitrogen concentration was higher in the oak-dominated natural forest $(0.81 \%)$ compared to the Stone pine plantation $(0.51 \%)$. The carbon content per hectare was almost 4 times higher in the natural forest than in the Stone pine plantation due to the high amount of forest floor mass in the natural forest. The nitrogen content was found to be 0.04 ton/ha and 0.22 ton/ha, respectively, for the Stone pine plantation and the natural forest. $\mathrm{C} / \mathrm{N}$ ratio was determined to be higher (94.21) in the Stone pine plantation where the nitrogen content was lower although both sites had a very similar carbon content (Table 3).

\section{Soil properties}

The soil sand content ranged from $81.25 \%$ to $88.25 \%$ in the natural forest, which was markedly higher compared to the other two sites. The clay mine spoil was found to have the lowest soil sand content, which was 38.05-43.25\%. The soil clay content was 
much lower in the natural forest compared to the other two sites and ranged from $7.23 \%$ to $11.35 \%$. The clay mine spoil had the highest soil clay content, ranging from $41.50 \%$ to $43.13 \%$ (Table 4 ). When the sites were compared as regards the texture type of soil, the main soil texture type was loamy sand in the natural forest while it was heavy clay in the clay mine spoil. The soil texture in the Stone pine plantation was mainly sandy clay.

Table 3. Comparison of forest floor variables between natural forest and stone pine plantation

\begin{tabular}{c|c|c|c|c|c|c}
\hline Plots & $\begin{array}{c}\text { Forest floor } \\
\text { mass } \\
\text { (ton/ha) }\end{array}$ & $\begin{array}{c}\text { Carbon } \\
(\mathbf{C}, \boldsymbol{\%})\end{array}$ & $\begin{array}{c}\text { Nitrogen } \\
(\mathbf{N}, \mathbf{\%})\end{array}$ & $\begin{array}{c}\text { Carbon mass } \\
(\text { ton/ha) }\end{array}$ & $\begin{array}{c}\text { Nitrogen mass } \\
\text { (ton/ha) }\end{array}$ & $\mathbf{C} / \mathbf{N}$ \\
\hline Natural & 28.07 & 40.91 & 0.81 & 11.47 & 0.22 & 55.93 \\
forest & $\pm 3.81^{\mathrm{b}}$ & $\pm 6.17^{\mathrm{a}}$ & $\pm 0.26^{\mathrm{b}}$ & $\pm 2.24^{\mathrm{b}}$ & $\pm 0.07^{\mathrm{b}}$ & $\pm 20.48^{\mathrm{a}}$ \\
Stone pine & 6.79 & 40.06 & 0.51 & 2.71 & 0.04 & 94.21 \\
plantation & $\pm 0.58^{\mathrm{a}}$ & $\pm 7.96^{\mathrm{a}}$ & $\pm 0.22^{\mathrm{a}}$ & $\pm 0.52^{\mathrm{a}}$ & $\pm 0.01^{\mathrm{a}}$ & $\pm 45.56^{\mathrm{b}}$ \\
Sig. & 0.000 & 0.647 & 0.000 & 0.000 & 0.000 & 0.000 \\
(2-tailed) & & &
\end{tabular}

\pm standard deviation, Means within columns following by the same letter are not statistically different at 0.05 significance level in two independent samples t-test

Table 4. Soil properties

\begin{tabular}{|c|c|c|c|c|c|}
\hline Soil depth & Properties & Natural forest & Stone pine plantation & Clay mine spoil & $\boldsymbol{P}$ \\
\hline \multirow{11}{*}{$0-5 \mathrm{~cm}$} & Sand (\%) & $81.25 \pm 10.02^{\mathrm{c}}$ & $50.75 \pm 8.20^{\mathrm{b}}$ & $41.75 \pm 8.64^{\mathrm{a}}$ & 0.000 \\
\hline & Silt (\%) & $7.40 \pm 7.47^{\mathrm{a}}$ & $8.40 \pm 6.74^{\mathrm{a}}$ & $16.75 \pm 7.10^{\mathrm{b}}$ & 0.001 \\
\hline & Clay (\%) & $11.35 \pm 6.57^{\mathrm{a}}$ & $40.85 \pm 5.73^{\mathrm{b}}$ & $41.50 \pm 6.58^{\mathrm{b}}$ & 0.000 \\
\hline & $\begin{array}{l}\text { Bulk density } \\
(<2 \mathrm{~mm}, \mathrm{~g} / \mathrm{l})\end{array}$ & $752.07 \pm 153.98^{\mathrm{a}}$ & $1190.15 \pm 108.23^{b}$ & $1242.76 \pm 161.49^{b}$ & 0.000 \\
\hline & $\mathrm{pH}$ & $5.33 \pm 0.43^{b}$ & $5.69 \pm 0.64^{b}$ & $4.07 \pm 0.76^{\mathrm{a}}$ & 0.000 \\
\hline & $\mathrm{EC}(\mu \mathrm{s} / \mathrm{cm})$ & $130.69 \pm 99.76^{\mathrm{a}}$ & $97.01 \pm 42.94^{\mathrm{a}}$ & $133.80 \pm 144.02^{\mathrm{a}}$ & 0.702 \\
\hline & $\mathrm{C}(\%)$ & $4.092 \pm 0.750^{\mathrm{c}}$ & $2.060 \pm 0.519^{\mathrm{b}}$ & $1.292 \pm 0.350^{\mathrm{a}}$ & 0.000 \\
\hline & $\mathrm{N}(\%)$ & $0.390 \pm 0.060^{c}$ & $0.056 \pm 0.012^{\mathrm{b}}$ & $0.029 \pm 0.009^{\mathrm{a}}$ & 0.000 \\
\hline & $\mathrm{C} / \mathrm{N}$ & $10.59 \pm 1.82^{\mathrm{a}}$ & $36.91 \pm 9.59^{\mathrm{b}}$ & $45.51 \pm 14.70^{\mathrm{b}}$ & 0.000 \\
\hline & $\mathrm{C}$ (ton/ha) & $15.078 \pm 2.517^{\mathrm{c}}$ & $12.222 \pm 3.215^{b}$ & $7.927 \pm 2.041^{\mathrm{a}}$ & 0.000 \\
\hline & $\mathrm{N}$ (ton/ha) & $1.464 \pm 0.366^{\mathrm{b}}$ & $0.338 \pm 0.079^{\mathrm{a}}$ & $0.182 \pm 0.053^{\mathrm{a}}$ & 0.000 \\
\hline \multirow{11}{*}{$5-15 \mathrm{~cm}$} & Sand (\%) & $83.05 \pm 10.11^{\mathrm{b}}$ & $50.05 \pm 8.13^{\mathrm{a}}$ & $43.25 \pm 10.54^{\mathrm{a}}$ & 0.000 \\
\hline & Silt (\%) & $6.08 \pm 2.73^{\mathrm{a}}$ & $8.42 \pm 6.57^{\mathrm{a}}$ & $13.90 \pm 6.25^{\mathrm{b}}$ & 0.002 \\
\hline & Clay $(\%)$ & $10.87 \pm 8.36^{\mathrm{a}}$ & $41.53 \pm 3.56^{\mathrm{b}}$ & $42.85 \pm 7.51^{\mathrm{b}}$ & 0.000 \\
\hline & $\begin{array}{l}\text { Bulk density } \\
(<2 \mathrm{~mm}, \mathrm{~g} / \mathrm{l})\end{array}$ & $1075.34 \pm 133.01^{\mathrm{a}}$ & $1258.12 \pm 169.90^{\mathrm{b}}$ & $1316.28 \pm 159.91^{b}$ & 0.000 \\
\hline & $\mathrm{pH}$ & $5.10 \pm 0.39^{b}$ & $5.38 \pm 0.38^{\mathrm{b}}$ & $4.11 \pm 0.79^{\mathrm{a}}$ & 0.000 \\
\hline & $\mathrm{EC}(\mu \mathrm{s} / \mathrm{cm})$ & $46.70 \pm 19.83^{\mathrm{a}}$ & $82.69 \pm 39.27^{\mathrm{a}}$ & $128.20 \pm 131.57^{\mathrm{a}}$ & 0.096 \\
\hline & $\mathrm{C}(\%)$ & $2.767 \pm 0.271^{\mathrm{c}}$ & $1.604 \pm 0.412^{\mathrm{b}}$ & $1.139 \pm 0.293^{\mathrm{a}}$ & 0.000 \\
\hline & $\mathrm{N}(\%)$ & $0.229 \pm 0.045^{\mathrm{c}}$ & $0.051 \pm 0.009^{\mathrm{b}}$ & $0.028 \pm 0.008^{\mathrm{a}}$ & 0.000 \\
\hline & $\mathrm{C} / \mathrm{N}$ & $12.51 \pm 3.14^{\mathrm{a}}$ & $32.47 \pm 10.88^{\mathrm{b}}$ & $41.81 \pm 13.86^{\mathrm{b}}$ & 0.000 \\
\hline & $\mathrm{C}$ (ton/ha) & $29.876 \pm 5.411^{\mathrm{c}}$ & $20.371 \pm 6.823^{b}$ & $14.906 \pm 3.914^{\mathrm{a}}$ & 0.000 \\
\hline & $\mathrm{N}$ (ton/ha) & $2.498 \pm 0.696^{\mathrm{b}}$ & $0.650 \pm 0.157^{\mathrm{a}}$ & $0.377 \pm 0.112^{\mathrm{a}}$ & 0.000 \\
\hline \multirow{4}{*}{$15-30 \mathrm{~cm}$} & Sand $(\%)$ & $88.05 \pm 4.15^{\mathrm{c}}$ & $48.65 \pm 9.19^{b}$ & $38.05 \pm 10.81^{\mathrm{a}}$ & 0.000 \\
\hline & Silt (\%) & $4.72 \pm 2.66^{\mathrm{a}}$ & $9.74 \pm 8.34^{\mathrm{a}}$ & $18.82 \pm 7.59^{\mathrm{b}}$ & 0.000 \\
\hline & Clay (\%) & $7.23 \pm 1.70^{\mathrm{a}}$ & $41.61 \pm 5.59^{b}$ & $43.13 \pm 8.98^{\mathrm{b}}$ & 0.000 \\
\hline & $\begin{array}{l}\text { Bulk density } \\
(<2 \mathrm{~mm}, \mathrm{~g} / \mathrm{l})\end{array}$ & $1157.82 \pm 43.55^{\mathrm{a}}$ & $1221.00 \pm 94.82^{\mathrm{a}}$ & $1161.08 \pm 216.52^{\mathrm{a}}$ & 0.597 \\
\hline
\end{tabular}




\begin{tabular}{c|c|c|c|c|c}
\hline $\mathrm{pH}$ & $5.30 \pm 0.32^{\mathrm{b}}$ & $5.34 \pm 0.77^{\mathrm{b}}$ & $3.42 \pm 0.95^{\mathrm{a}}$ & 0.000 \\
$\mathrm{EC}(\mu \mathrm{s} / \mathrm{cm})$ & $29.97 \pm 10.21^{\mathrm{a}}$ & $77.76 \pm 39.76^{\mathrm{a}}$ & $389.28 \pm 460.56^{\mathrm{b}}$ & 0.010 \\
$\mathrm{C}(\%)$ & $2.356 \pm 0.220^{\mathrm{c}}$ & $1.485 \pm 0.361^{\mathrm{b}}$ & $0.993 \pm 0.369^{\mathrm{a}}$ & 0.000 \\
$\mathrm{~N}(\%)$ & $0.148 \pm 0.034^{\mathrm{c}}$ & $0.054 \pm 0.013^{\mathrm{b}}$ & $0.025 \pm 0.009^{\mathrm{a}}$ & 0.000 \\
$\mathrm{C} / \mathrm{N}$ & $16.56 \pm 3.92^{\mathrm{a}}$ & $29.49 \pm 12.83^{\mathrm{b}}$ & $42.09 \pm 19.42^{\mathrm{b}}$ & 0.000 \\
& $\mathrm{C}$ (ton/ha) & $40.860 \pm 3.303^{\mathrm{c}}$ & $27.351 \pm 7.578^{\mathrm{b}}$ & $17.533 \pm 7.592^{\mathrm{a}}$ & 0.000 \\
$\mathrm{~N}$ (ton/ha) & $2.593 \pm 0.649^{\mathrm{c}}$ & $1.002 \pm 2.249^{\mathrm{b}}$ & $0.431 \pm 0.137^{\mathrm{a}}$ & 0.000 \\
\hline
\end{tabular}

\pm standard deviation, means within rows following by the same letter are not statistically different at 0.05 significance level in Duncan Post-Hoc Test

The mean soil bulk density was found to be statistically significantly different and lower in the natural forest compared to the other two sites at depths of 0-5 and 5-15 $\mathrm{cm}$. At these two depths, the highest mean soil bulk density was found in the clay mine spoil whereas the lowest was in the natural forest. At the deepest layer which was 15$30 \mathrm{~cm}$, there was no statistically significant difference between the sites as regards mean soil bulk density (Table 4).

As for soil $\mathrm{pH}$; it was statistically significantly different in the clay mine spoil compared to the other sites at three depths, which was lower compared to the soil $\mathrm{pH}$ in the Stone pine plantation and natural forest (Table 4). There was no statistically significant difference as regards mean soil EC between the three sites at depths of 0-5 and $5-15 \mathrm{~cm}$. The soil EC was higher in the clay mine spoil $(389.28 \mu \mathrm{s} / \mathrm{cm})$ at the depth of $15-30 \mathrm{~cm}$ compared to the other two sites, which was statistically significantly different (Table 4).

There was a statistically significant difference in soil carbon and nitrogen concentrations between three sites at all depths. The highest carbon and nitrogen concentrations at all depths were found in the natural forest while the lowest values were found in the clay mine spoil. The soil carbon and nitrogen concentrations in the Stone pine plantation were in the range between the values of the other two sites. The carbon and nitrogen concentrations at the depth of $0-5 \mathrm{~cm}$ where the values are the highest are ranked from the highest to the lowest as follows: $0.390-4.092 \%$, in the natural forest; $0.056-2.060 \%$ in the Stone pine plantation, and $0.029-1.292 \%$ in the clay mine spoil (Table 4 ). As for $\mathrm{C} / \mathrm{N}$ ratio, there were statistical differences at all three depths between the natural forest, Stone pine plantation and mine spoil. The lowest $\mathrm{C} / \mathrm{N}$ ratio for all depths was found in the natural forest while the highest was found in the mine spoil (Table 4). The total carbon storage per hectare was statistically significantly different in three different sites at all three depths in parallel to soil carbon content. At the depth of $0-30 \mathrm{~cm}$ in all sites, the total carbon storage per hectare was ranked from the highest to the lowest as follows: 85.814 ton/ha $(15.078+29.876+$ $40.860)$ in the natural forest, 59.944 ton/ha $(12.222+20.371+27.351)$ in the Stone pine plantation, and 40.366 ton/ha $(7.927+14.906+17.533)$ in the clay mine spoil. The highest nitrogen storage per hectare at the depth of $0-30 \mathrm{~cm}$ was found as 6.555 ton/ha $(1.464+2.498+2.593)$ in the natural forest followed by the Stone pine plantation with 1.990 ton/ha $(0.338+0.650+1.002)$, while the lowest was found to be 0.990 ton/ha $(0.182+0.377+0.431)$ in the clay mine spoil, which was similar to total carbon storage (Table 4). 


\section{Discussion}

\section{Forest floor}

The forest floor from the tree species planted in mine sites provide important benefits including primarily nutrients such as carbon and nitrogen (Frouz et al., 2013). Similar results were obtained in this study as regards forest floor carbon and nitrogen concentrations, which were consistent with the previous studies. Polat (2010) found that the forest floor carbon concentration in Stone pine plantations ranged from 39\% to 55\% at different layers. Keskin and Makineci (2009) reported that the mean forest floor organic carbon content ranged from $38 \%$ to $51 \%$ and nitrogen content from $0.5 \%$ to $0.8 \%$ in coal mine sites reclaimed with Stone pine plantation trials in Istanbul-Ağaçlı. The forest floor carbon concentration in the natural oak forest was also similar to the ones reported by other studies. For example, the forest floor carbon ranges from $39 \%$ to 44\% across different oak stands in Turkey and their forest floor nitrogen concentration is approximately 1\% (Akburak, 2013; Çakır, 2013; Makineci et al., 2015). Walmsley et al. (2019) reported that the nitrogen concentration was $0.53 \%$ and $0.36 \%$, respectively, in the forest floor of oak (Quercus robur) and pine (Pinus spp.) planted in mine sites and biological activity was lower in the forest floor with high $\mathrm{C} / \mathrm{N}$ ratio like as for pine species.

Forest floor accumulated in 24 years in the Stone pine plantation, which was found to cover around $50 \%$ of the soil due to planting density. Our observations and findings revealed that decomposition of Stone pine forest floor was not fast on clay mine spoils. Poor decomposition may be the result of poor physical soil properties, high bulk density and high clay content leading to poor water and air drainage conditions as well as slower biological activity of the severely acidic substrate. Moreover, high $\mathrm{C} / \mathrm{N}$ ratio of Stone pine forest floor lead to slow decomposition. Similarly, previous studies reported that the forest floor of Stone pine plantations decomposed slowly under limited conditions such as mine sites and dunes (Keskin and Makineci, 2009; Polat, 2010; Abdalmoula et al., 2019). Forest floor decomposition and carbon to nitrogen ratio vary depending on several factors such as habitat and the chemical properties of the forest floor (Kantarc1, 2000; Treschevskaya et al., 2019).

\section{Soil properties}

\section{Soil texture, sand, silt, clay ratios}

As a significant difference between the sites as regards soil type as one of the physical soil properties, the soils in the natural forest had a very high sand content while the other sites had a high clay content. The significant difference between sand contents was because the natural structure of the geological material in the forest was sandy. Large pits are created as this material is removed during surface mining. After the mine is abandoned, the excavated clay mine tailings-spoils mix with the material from different depths having different physical properties to use this very heterogeneous material to level the site. Natural soil mixes due to excavation, stockpiling, and replacement operations because of the reclamation activities during and after mining. Therefore, a material that has very different properties than the natural forest structure is formed.

In a similar study, Mosseler and Major (2017) found that one of two adjacent mining tailings sites had a high soil clay content while the another was an abandoned shale overburden site. Two different Salix species (Salix discolor and Salix eriocephala) were 
tried in those sites. The clay content was found to be higher than $42 \%$ in the site with high soil clay content while the shale overburden site had a higher sand content $(67.2 \%)$ (Mosseler and Major, 2017). Contrary to our results, Shrestha and Lal (2011) and Yuan et al. (2017) reported that the reclaimed mine site had a higher sand content and they associated it with the high sand content of the material. However, they also reported that clay content increased depending on weathering in the reclaimed sites in the following years compared to the initial years. These findings show that different results can be obtained depending on the structural characteristics of the material. The research area in our study was a clay mine spoil which had a high clay content. On the contrary, the soil in the natural forest had a higher sand content.

\section{Bulk density}

The bulk density at all three depths in the study was significantly higher in the Stone pine plantation and clay mine spoil compared to the natural forest. The highest mean bulk density $(<2 \mathrm{~mm})$ was found to be $1316 \mathrm{~g} / \mathrm{l}$. There was a significant difference between the Stone pine plantation and mine site spoil. High bulk density is an expected result in reclaimed mine sites, which is increased due to the compaction of the soil by heavy duty vehicles during the leveling of the soil (Ussiri et al., 2006). Moreover, the material is highly mixed in mine sites and areas reclaimed on mine spoils and has different physical properties. In our study, it can be suggested that increased organic carbon content especially at the topsoil layer $(0-5 \mathrm{~cm})$ in the plantation did not reach the level that could change the soil bulk density. In this case, the heterogeneous physical properties of the mixed material are the determining factor. Increased bulk density an important physical soil property for plant growth because it affects water retention capacity and drainage conditions by decreasing soil pore volume (Asensio et al., 2013).

Several studies have reported that organic carbon content is low in mine sites and soil bulk density increases due to compaction and properties of the material (Keskin and Makineci, 2009; Sever and Makineci, 2009; Ahirwal and Maiti, 2016; Gu et al., 2019). Shrestha and Lal (2011) reported that soil bulk density at the depth of $0-15 \mathrm{~cm}$ in reclaimed mine sites was $54 \%$ higher than the one in the protected areas. Ussiri et al. (2006) stated that soil bulk density can be as high as $1.82 \mathrm{Mg} \mathrm{m}^{-3}$ in reclaimed mine sites due to the compaction of the soil by heavy duty vehicles, Maiti (2007) reported that bulk density was $2040 \mathrm{~g} / \mathrm{l}$ at the topsoil layer of non-reclaimed mine sites and 1760 $\mathrm{g} / \mathrm{l}$ in reclaimed mine soil. Besides, Ganjegunte et al. (2009) did not find any difference in bulk density between the reclaimed site and protected area at the depth of $0-30 \mathrm{~cm}$.

\section{$p H$ and $E C$}

Soil chemical properties which include $\mathrm{pH}, \mathrm{EC}, \mathrm{C}, \mathrm{N}$ and $\mathrm{C} / \mathrm{N}$ ratio are affected substantially by mining and reclamation activities.

Acidic soil reaction was usually observed in all sites whereas very low $\mathrm{pH}$ values were measured in the mine spoil. Soil $\mathrm{pH}$ was higher in the Stone pine plantation at each depth compared to the other sites. Because the mixed material has a completely different character in mine sites, $\mathrm{pH}$ might vary significantly due to the heterogeneous structure. In fact, Rodríguez-Vila et al. (2016) reported that $\mathrm{pH}$ varied in a wide range from 2.7 to 9.03 . Changing $\mathrm{pH}$ is an expected result after plantation while soil $\mathrm{pH}$ tends to increase in reclaimed sites (Ussiri et al., 2006; Chatterjee et al., 2009; Liu et al., 2017; Gu et al., 2019). 
Depending on soil $\mathrm{pH}$ values in acidic soils, soil EC is usually low and salinity problem is not expected for plant growth. Besides, difference between the sites only at the depth of $15-30 \mathrm{~cm}$ was significant. Soils with low $\mathrm{pH}$ usually have low salinity (Mosseler and Major, 2017).

Soil $\mathrm{pH}$ and EC variations are affected by the properties of the geological materials of the sites and those of the material that is formed after mining operations. Carbonates, lime, different dissoluble chemical compounds contained in these material and chemical contamination with the material have an important impact on $\mathrm{pH}$ (Shrestha and Lal, 2011; Mukhopadhyay et al., 2013). Additionally, Yuan et al. (2017) reported that substances contained in the decomposed litter (humic acid, organic acid and fulvic acid) also affected soil $\mathrm{pH}$.

\section{$C$ and $N$}

Mine spoils usually have a very low organic matter-carbon content. Treschevskaya et al. (2019) reported that almost the whole soil organic matter disappeared due to mining operations, while Akala and Lal (2001) stated that $70 \%$ of soil organic matter disappeared. Soil carbon is very important as the main source of soil nutrients, for soil ecology and its biological properties, climate change and carbon balance as well as improvement of water retention and drainage conditions. It is indeed the main subject of several similar studies. Moreover, nitrogen is a primary nutrient for all living organisms and organic matter is the main source of nitrogen in terrestrial ecosystems. In this scope, low organic carbon content in mine sites to be reclaimed is important as it limits plant growth and nutrition. However, increased carbon content in a reclaimed site is a crucial indicator of the improvement of the site.

Organic carbon and nitrogen contents at three depths were significantly different in the sites studied in this research, which increased in mine spoil, Stone pine plantation and natural forest, respectively. The main reason for increased nitrogen content must be the high organic carbon content. This result demonstrated that Stone pine could adapt to the poor environment of the mine spoil and can grow after plantation, which supplied organic matter to the soil. However, the organic carbon and nitrogen concentrations were nearly half of the values in the natural forest even in 24 years after plantation, which indicated that a long time was needed for development. Because of huge degradations on soil and land via surface mining activities, the natural forest soil differs in nature from the one being remediated. Also, it is not possible to reach the same level of soil health status under the plantation at all. Liu et al. (2017) reported that although soil organic matter increased through reclamation after mining operations, it required a long time even decades for it to reach the levels under natural conditions. Cui et al. (2012) stated that it required more than 40 years. In some circumstances, the species of trees planted in mine reclamation sites have important effects on the soil but the question if these effects are the result of the properties of the material or the characteristics specific to the tree species could not be answered (Józefowska et al., 2016).

Slow decomposition due to high $\mathrm{C} / \mathrm{N}$ ratio as a result of forest floor properties is another possible reason for low organic carbon content in Stone pine plantations. Similarly, Yuan et al. (2017) reported that soil organic carbon and nitrogen increased in reclaimed mine sites, $\mathrm{C} / \mathrm{N}$ ratio changed very differently but reclaimed mine sites had a higher $\mathrm{C} / \mathrm{N}$ ratio. 
Similar results have been demonstrated by similar studies on Stone pine plantations. For example, organic carbon concentration in Stone pine plantations was reported to be $0.07-0.56 \%$ (Atmaca and Y1lmaz, 2006), 0.30\% (Kizildag et al., 2012) and 0.6- 7.0\% (K1lc1 et al., 2000). In addition, organic carbon content was found to be $0.13-2.74 \%$ and nitrogen content to be $0.02-0.407 \%$ in reclaimed coal mine sites with Stone pine plantations (Keskin and Makineci, 2009).

Soil organic carbon and nitrogen may vary highly in natural oak forests. In fact, various studies revealed that soil carbon content was $0.02-10.5 \%$ in natural oak forests, and thus nitrogen and $\mathrm{C} / \mathrm{N}$ ratio might differ substantially (Akburak, 2013; Çakır, 2013; Makineci et al., 2015).

\section{Conclusion}

The most important conclusion of the study is that Stone pine could survive and growth on mine spoils that have very poor physical and chemical properties under the ecological conditions of the research area. Moreover, 24 years after plantation, soil organic carbon sequestration has been limited despite the forest floor accumulation under Stone pine. Soil carbon and nitrogen contents in the plantation are still half of the natural forest and it requires a long time for restoration.

The extent of such changes and differences may vary depending on the type of mineral, mining method, substrate properties, selected tree species, habitat conditions and etc. Furthermore, reclamation technique may also result in differences. The land was just leveled; soil laying, nutrient supplementation, fertilization or any other soil rehabilitation were not performed. The limitation of the study was that only a limited number of sampling was performed and it was sampled just once. There is a need for further studies to collect more information about the reclamation of these sites through sampling a larger area with higher repetitions.

Acknowledgements. This study contains data from the Master of Science thesis of Cemil Külcüoğlu in The Institute of Graduate Education, Isparta University of Applied Science under supervision of Dr. Yasin Karatepe and co-supervision of Dr. Ender Makineci.

\section{REFERENCES}

[1] Abdalmoula, M. M., Makineci, E., Özturna, A. G., Pehlivan, S., Şahin, A., Tolunay, D. (2019): Soil organic carbon accumulation and several physicochemical soil properties under stone pine and maritime pine plantations in coastal dune, Durusu-Istanbul. Environmental Monitoring and Assessment 191(5): 312.

[2] Ahirwal, J., Maiti, S. K. (2016): Assessment of soil properties of different land uses generated due to surface coal mining activities in tropical Sal (Shorea robusta) forest, India. - Catena 140: 155-163.

[3] Akala, V. A., Lal, R. (2001): Soil organic pools and sequestration rates in reclaimed minesoils in Ohio. - Journal of Environmental Quality 30: 2090-2104.

[4] Akburak, S. (2013): The effects of thinning on soil respiration and microbial respiration in oak and hornbeam stands. (Saf meşe ve gürgen meşcerelerinde farklı aralama şiddetlerinde toprak solunumu ve mikrobiyal solunumun zamansal değişimi). - PhD thesis, Istanbul University Science Institute, Istanbul. (in Turkish). 
[5] Asensio, V., Vega, F. A., Andrade, M. L., Covelo, E. F. (2013): Tree vegetation and waste amendments to improve the physical condition of copper mine soils. Chemosphere 90(2): 603-610.

[6] Atmaca, F., Y1lmaz, K. T. (2006): Effect of Turan Emeksiz coastal dune afforestation on some soil properties. (Turan Emeksiz kıyı kumul ağaçlandırmasının bazı toprak özellikleri üzerine etkisi). - Eastern Mediterranean Forestry Research Institute Journal 12: 207-226. (in Turkish).

[7] Burton, P. J., Macdonald, S. E. (2011): The restorative imperative: challenges, objectives and approaches to restoring naturalness in forests. - Silva Fennica 45: 843-863.

[8] Chatterjee, A., Lal, R., Shrestha, R. K., Ussiri, D. A. N. (2009): Soil carbon pools of reclaimed minesoils under grass and forest land uses. - Land Degradation and Development 20: 300-307.

[9] Cui, J., Liu, C., Li, Z. L., Wang, L., Chen, X. F., Ye, Z. Z., Fang, C. M. (2012): Longterm changes in topsoil chemical properties under centuries of cultivation after reclamation of coastal wetlands in the Yangtze Estuary, China. - Soil Tillage Research 123: 50-60.

[10] Çakır, M. (2013): Seasonal changes of soil arthropods in beech and oak ecosystems and their effects on litter decomposition. (Toprak eklembacaklılarının, kayın ve meşe ekosistemindeki mevsimsel değişimi ve ölü örtü ayrışmasına etkileri). - PhD thesis, Istanbul University Science Institute, Istanbul. (in Turkish).

[11] Demir, B. G., Akbulut, A., Güngör, N. (2016): Geology of the Şile (İstanbul) Neogene Basin and the importance of the basin in terms of quartz sand. (Şile (İstanbul) Neojen Havzası'nın jeolojisi ve havzanın kuvars kumu açısından önemi). - 69th Geological Congress of Turkey, 11-15 April 2016, Geopolitics of Natural Resources Abstracts Book, Ankara. (in Turkish).

[12] Dönmez, Y. (1979): Plant Geography of Kocaeli Peninsula. (Kocaeli Yarımadasının Bitki Coğrafyası). - University of Istanbul Publication, Istanbul. (in Turkish).

[13] Ertek, A., Kozak, R., Evren, E. N. (1998): Natural history and cultural structure of Şile, socio-economic analysis and development strategies. (Şile doğal tarihi ve kültürel yapısı, sosyo-ekonomik analizi ve gelişme stratejileri). - Mataş Publication, Istanbul. (in Turkish).

[14] Frouz, J., Livečková, M., Albrechtová, J., Chroňáková, A., Cajthaml, T., Pižl, V., Háněl, L., Starı, J., Baldrian, P., Lhotáková, Z. (2013): Is the effect of trees on soil properties mediated by soil fauna? A case study from post-mining sites. - Forest Ecology and Management 309: 87-95.

[15] Frouz, J., Vobořilová, V., Janoušová, I., Kadochová, Š., Matějíček, L. (2015): Spontaneous establishment of late successional tree species English oak (Quercus robur) and European beech (Fagus sylvatica) at reclaimed alder plantation and unreclaimed post mining sites. - Ecological Engineering 77: 1-8.

[16] Ganjegunte, G. K., Wick, A. F., Stahl, P. D., Vance, G. F. (2009): Accumulation and composition of total organic carbon in reclaimed coal mine lands. - Land Degradation and Development 20: 156-175.

[17] Gençay, G., Birben, Ü., Durkaya, B. (2018): Effects of legal regulations on land use change: 2/B applications in Turkish forest law. - Journal of Sustainable Forestry 37(8): 804-819.

[18] Gu, L. P., Kong, J. J., Chen, K., Guo, Y. Q. (2019): Monitoring soil biological properties during the restoration of a phosphate mine under different tree species and plantation types. - Ecotoxicology and Environmental Safety 180: 130-138.

[19] Józefowska, A., Woś, B., Pietrzykowski, M. (2016): Tree species and soil substrate effects on soil biota during early soil forming stages at afforested mine sites. - Applied Soil Ecology 102: 70-79. 
[20] Juwarkar, A. A., Mehrotra, K. L., Nair, R., Wanjari, T., Singh, S. K., Chakrabarti, T. (2010): Carbon sequestration in reclaimed manganese mine land at Gumgaon, India. Environmental Monitoring and Assessment 160: 457-464.

[21] Kantarc1, M. D. (2000): Soil science. (Toprak ilmi). - University of Istanbul Faculty of Forestry Publication, Istanbul. (in Turkish).

[22] Karaöz, Ö. (1989a): Laboratory analyze methods of some physical soil properties related to water holding capacity. (Toprakların su ekonomisine ilişkin bazı fiziksel özelliklerinin laboratuvarda belirlenmesi yöntemleri). - Review of the Faculty of Forestry, University of Istanbul 39(B2): 133-144. (in Turkish).

[23] Karaöz, Ö. (1989b): Analyze methods of some chemical soil properties (pH, carbonates, salinity, organic matter, total nitrogen, available phosphorus). (Toprakların bazı kimyasal özelliklerinin ( $\mathrm{pH}$, karbonat, tuzluluk, organik madde, total azot, yararlanılabilir fosfor) analiz yöntemleri). - Review of the Faculty of Forestry, University of Istanbul 39(B3): 64-82. (in Turkish).

[24] Keskin, T., Makineci, E. (2009): Some soil properties on coal mine spoils reclaimed with black locust (Robinia pceudoacacia L.) and umbrella pine (Pinus pinea L.) in AgacliIstanbul. - Environmental Monitoring and Assessment 159(1-4): 407.

[25] Kilc1, M., Sayman, M., Akbin, G. (2000): Factors affecting the development of stone pine (Pinus pinea L.) in Western Anatolia. (Batı Anadolu'da fistıkçamının (Pinus pinea L.) gelişmesini etkileyen faktörler). - Republic of Turkey Ministry of Forestry Publication, İzmir. (in Turkish).

[26] Kizildag, N., Aka Sagliker, H., Kutlay, A., Cenkseven, Ş., Darici, C. (2012): Some soil properties and microbial biomass of Pinus maritima, Pinus pinea and Eucalyptus camaldulensis from the Eastern Mediterranean coasts. - EurAsian Journal of Bioscience 6: 121-126.

[27] Liu, X., Bai, Z., Zhou, W., Cao, Y., Zhang, G. (2017): Changes in soil properties in the soil profile after mining and reclamation in an opencast coal mine on the Loess Plateau, China. - Ecological Engineering 98: 228-239.

[28] Maiti, S. K. (2007): Bioreclamation of coalmine overburden dumps - with special emphasis on micronutrients and heavy metals accumulation in tree species. Environmental Monitoring and Assessment 125: 111-122.

[29] Makineci, E., Özdemir, E., Çalışkan, S., Yılmaz, E., Kumbaşl1, M., Keten, A., Beşkardeş, V., Zengin, H., Y1lmaz, H. (2015): Ecosystem carbon pools of coppice-originated oak forests at different development stages. - European Journal of Forest Research 134(2): 319-333.

[30] Mosseler, A., Major, J. E. (2017): Phytoremediation efficacy of Salix discolor and S. eriocephela on adjacent acidic clay and shale overburden on a former mine site: Growth, soil, and foliage traits. - Forests 8(12): 475.

[31] Mukhopadhyay, S., Maiti, S. K. (2011): Trace metal accumulation and natural mycorrhizal colonisation in an afforested coalmine overburden dump: a case study from India. - International Journal of Mining, Reclamation and Environment 25(2): 187-207.

[32] Mukhopadhyay, S., Maiti, S. K., Masto, R. E. (2013): Use of Reclaimed Mine Soil Index (RMSI) for screening of tree species for reclamation of coal mine degraded land. Ecological Engineering 57: 133-142.

[33] Polat, O. (2010): Investigation of changes in soil properties of Turan Emeksiz Dune stone pine (Pinus pinea L.) plantations (Turan Emeksiz Kumulu fistık çamı (Pinus pinea L.) plantasyonlarının toprak özelliklerindeki değişimlerin irdelenmesi). - Master of Science thesis, Çukurova University Science Institute, Adana. (in Turkish).

[34] Rodríguez-Vila, A., Asensio, V., Forján, R., Covelo, E. F. (2016): Carbon fractionation in a mine soil amended with compost and biochar and vegetated with Brassica juncea L. Journal of Geochemical Exploration 169: 137-143. 
[35] Sever, H., Makineci, E. (2009): Soil organic carbon and nitrogen accumulation on coal mine spoils reclaimed with maritime pine (Pinus pinaster Aiton) in Agacli-Istanbul. Environmental Monitoring and Assessment 155(1-4): 273-280.

[36] Sezer, Y. (2006): Flora and vegetation of Şile and its surroundings (Istanbul). (Şile ve civarının (İstanbul) flora ve vejetasyonu). - Master of Science thesis, Bartın University Science Institute, Bartın. (in Turkish).

[37] Shrestha, R. K., Lal, R. (2011): Changes in physical and chemical properties of soil after surface mining and reclamation. - Geoderma 161(3-4): 168-176.

[38] Treschevskaya, E., Tichonova, E., Golyadkina, I., Malinina, T. (2019): Soil development processes under different tree species at afforested post-mining sites. - IOP Conference Series: Earth and Environmental Science, IOP Publishing 226: 012012.

[39] Ussiri, D. A. N., Lal, R., Jacinthe, P. A. (2006): Post-reclamation land use effects on properties and carbon sequestration in minesoils of southeastern Ohio. - Soil Science 171: 261-271.

[40] Walmsley, A., Vachová, P., Hlava, J. (2019): Tree species identity governs the soil macrofauna community composition and soil development at reclaimed post-mining sites on calcium-rich clays. - European Journal of Forest Research 138(4): 753-761.

[41] Yuan, Y., Zhao, Z., Zhang, P., Chen, L., Hu, T., Niu, S., Bai, Z. (2017): Soil organic carbon and nitrogen pools in reclaimed mine soils under forest and cropland ecosystems in the Loess Plateau, China. - Ecological Engineering 102: 137-144.

\section{APPENDIX}

Table A1. Base ANOVA results for $0-5 \mathrm{~cm}$ soil depth

\begin{tabular}{|c|c|c|c|c|c|c|}
\hline \multicolumn{2}{|c|}{ Properties } & Sum of Squares & df & $\begin{array}{l}\text { Mean } \\
\text { Square }\end{array}$ & $\mathbf{F}$ & Significance \\
\hline $\begin{array}{l}\text { Sand } \\
(\%)\end{array}$ & $\begin{array}{c}\text { Between Groups } \\
\text { Within Groups } \\
\text { Total }\end{array}$ & $\begin{array}{c}10531.875 \\
2929.100 \\
13460.975\end{array}$ & $\begin{array}{c}2 \\
37 \\
39\end{array}$ & $\begin{array}{c}5265.938 \\
79.165\end{array}$ & 66.519 & 0.000 \\
\hline $\begin{array}{l}\text { Silt } \\
(\%)\end{array}$ & $\begin{array}{c}\text { Between Groups } \\
\text { Within Groups } \\
\text { Total }\end{array}$ & $\begin{array}{c}788.225 \\
1870.070 \\
2658.295\end{array}$ & $\begin{array}{c}2 \\
37 \\
39\end{array}$ & $\begin{array}{c}394.113 \\
50.542\end{array}$ & 7.798 & 0.001 \\
\hline $\begin{array}{l}\text { Clay } \\
(\%)\end{array}$ & $\begin{array}{c}\text { Between Groups } \\
\text { Within Groups } \\
\text { Total }\end{array}$ & $\begin{array}{l}6722.850 \\
1509.770 \\
8232.620\end{array}$ & $\begin{array}{c}2 \\
37 \\
39\end{array}$ & $\begin{array}{c}3361.425 \\
40.805\end{array}$ & 82.379 & 0.000 \\
\hline $\begin{array}{l}\text { Bulk density } \\
(<2 \mathrm{~mm}, \mathrm{~g} / \mathrm{l})\end{array}$ & $\begin{array}{c}\text { Between Groups } \\
\text { Within Groups } \\
\text { Total }\end{array}$ & $\begin{array}{c}1697507.657 \\
814345.214 \\
2511852.871\end{array}$ & $\begin{array}{c}2 \\
37 \\
39\end{array}$ & $\begin{array}{c}848753.829 \\
22009.330\end{array}$ & 38.563 & 0.000 \\
\hline $\mathrm{pH}$ & $\begin{array}{c}\text { Between Groups } \\
\text { Within Groups } \\
\text { Total }\end{array}$ & $\begin{array}{l}21.273 \\
16.447 \\
37.719 \\
\end{array}$ & $\begin{array}{c}2 \\
37 \\
39\end{array}$ & $\begin{array}{c}10.636 \\
0.445\end{array}$ & 23.928 & 0.000 \\
\hline $\mathrm{EC}(\mu \mathrm{s} / \mathrm{cm})$ & $\begin{array}{c}\text { Between Groups } \\
\text { Within Groups } \\
\text { Total }\end{array}$ & $\begin{array}{c}9651.737 \\
500324.658 \\
509976.395\end{array}$ & $\begin{array}{c}2 \\
37 \\
39\end{array}$ & $\begin{array}{c}4825.869 \\
13522.288\end{array}$ & 0.357 & 0.702 \\
\hline $\mathrm{C}(\%)$ & $\begin{array}{c}\text { Between Groups } \\
\text { Within Groups } \\
\text { Total }\end{array}$ & $\begin{array}{l}52.473 \\
9.829 \\
62.302\end{array}$ & $\begin{array}{c}2 \\
37 \\
39\end{array}$ & $\begin{array}{c}26.236 \\
0.266\end{array}$ & 98.761 & 0.000 \\
\hline
\end{tabular}




\begin{tabular}{c|c|c|c|c|c|c}
\hline \multirow{2}{*}{$\mathrm{N}(\%)$} & Between Groups & 0.933 & 2 & 0.466 & 479.856 & \\
& Within Groups & 0.036 & 37 & 0.001 & & 0.000 \\
& Total & 0.969 & 39 & & & \\
\hline \multirow{3}{*}{$\mathrm{C} / \mathrm{N}$} & Between Groups & 8201.948 & 2 & 4100.974 & 30.539 & 0.000 \\
& Within Groups & 4968.519 & 37 & 134.284 & & \\
& Total & 13170.467 & 39 & & & 0.000 \\
$\mathrm{C}$ & Between Groups & 368.338 & 2 & 184.169 & 29.720 & \\
(ton/ha) & Within Groups & 229.283 & 37 & 6.197 & & \multirow{2}{*}{0.000} \\
& Total & 597.620 & 39 & & & \\
\hline \multirow{2}{*}{$\mathrm{N}$} & Between Groups & 11.499 & 2 & 5.750 & & \\
\hline
\end{tabular}

Table A2. Base ANOVA results for $5-15 \mathrm{~cm}$ soil depth

\begin{tabular}{|c|c|c|c|c|c|c|}
\hline \multicolumn{2}{|c|}{ Properties } & Sum of Squares & df & $\begin{array}{c}\text { Mean } \\
\text { Square }\end{array}$ & $\mathbf{F}$ & Significance \\
\hline $\begin{array}{l}\text { Sand } \\
(\%)\end{array}$ & $\begin{array}{c}\text { Between Groups } \\
\text { Within Groups } \\
\text { Total }\end{array}$ & $\begin{array}{l}10873.900 \\
3630.000 \\
14503.900\end{array}$ & $\begin{array}{c}2 \\
37 \\
39\end{array}$ & $\begin{array}{c}5436.950 \\
98.108\end{array}$ & 55.418 & 0.000 \\
\hline $\begin{array}{l}\text { Silt } \\
(\%)\end{array}$ & $\begin{array}{c}\text { Between Groups } \\
\text { Within Groups } \\
\text { Total }\end{array}$ & $\begin{array}{c}469.603 \\
1199.372 \\
1668.975\end{array}$ & $\begin{array}{c}2 \\
37 \\
39\end{array}$ & $\begin{array}{c}234.802 \\
32.415\end{array}$ & 7.244 & 0.002 \\
\hline $\begin{array}{l}\text { Clay } \\
(\%)\end{array}$ & $\begin{array}{c}\text { Between Groups } \\
\text { Within Groups } \\
\text { Total }\end{array}$ & $\begin{array}{l}7472.403 \\
1816.172 \\
9288.575\end{array}$ & $\begin{array}{c}2 \\
37 \\
39\end{array}$ & $\begin{array}{c}3736.202 \\
49.086\end{array}$ & 76.116 & 0.000 \\
\hline $\begin{array}{l}\text { Bulk density } \\
(<2 \mathrm{~mm}, \mathrm{~g} / \mathrm{l})\end{array}$ & $\begin{array}{c}\text { Between Groups } \\
\text { Within Groups } \\
\text { Total }\end{array}$ & $\begin{array}{c}390709.622 \\
904947.905 \\
1295657.528\end{array}$ & $\begin{array}{c}2 \\
37 \\
39\end{array}$ & $\begin{array}{c}195354.811 \\
24458.051\end{array}$ & 7.987 & 0.001 \\
\hline $\mathrm{pH}$ & $\begin{array}{c}\text { Between Groups } \\
\text { Within Groups } \\
\text { Total }\end{array}$ & $\begin{array}{l}13.079 \\
14.700 \\
27.780\end{array}$ & $\begin{array}{c}2 \\
37 \\
39\end{array}$ & $\begin{array}{l}6.540 \\
0.397\end{array}$ & 16.460 & 0.000 \\
\hline $\mathrm{EC}(\mu \mathrm{s} / \mathrm{cm})$ & $\begin{array}{c}\text { Between Groups } \\
\text { Within Groups } \\
\text { Total }\end{array}$ & $\begin{array}{c}46811.601 \\
346350.739 \\
393162.340\end{array}$ & $\begin{array}{c}2 \\
37 \\
39\end{array}$ & $\begin{array}{l}23405.801 \\
9360.831\end{array}$ & 2.500 & 0.096 \\
\hline $\mathrm{C}(\%)$ & $\begin{array}{c}\text { Between Groups } \\
\text { Within Groups } \\
\text { Total }\end{array}$ & $\begin{array}{l}17.715 \\
3.837 \\
21.552\end{array}$ & $\begin{array}{c}2 \\
37 \\
39\end{array}$ & $\begin{array}{l}8.858 \\
0.104\end{array}$ & 85.406 & 0.000 \\
\hline $\mathrm{N}(\%)$ & $\begin{array}{l}\text { Between Groups } \\
\text { Within Groups }\end{array}$ & $\begin{array}{l}0.284 \\
0.021\end{array}$ & $\begin{array}{c}2 \\
37\end{array}$ & $\begin{array}{l}0.142 \\
0.001\end{array}$ & 249.838 & 0.000 \\
\hline
\end{tabular}




\begin{tabular}{c|c|c|c|c|c|c} 
& Total & 0.305 & 39 & & & \\
\hline \multirow{3}{*}{$\mathrm{C} / \mathrm{N}$} & Between Groups & 5725.598 & 2 & 2862.799 & 22.020 & \\
& Within Groups & 4810.323 & 37 & 130.009 & & 0.000 \\
& Total & 10535.921 & 39 & & & \\
\hline \multirow{2}{*}{$\mathrm{C}$} & Between Groups & 1495.635 & 2 & 747.817 & 28.417 & \\
$($ ton/ha) & Within Groups & 973.672 & 37 & 26.315 & & \\
& Total & 2469.307 & 39 & & & \\
\hline \multirow{2}{*}{$\mathrm{N}$} & Between Groups & 31.391 & 2 & 15.696 & 120.254 & \\
$($ ton/ha) & Within Groups & 4.829 & 37 & 0.131 & & 0.000 \\
& Total & 36.221 & 39 & & & \\
\hline
\end{tabular}

Table A3. Base ANOVA results for $15-30 \mathrm{~cm}$ soil depth

\begin{tabular}{|c|c|c|c|c|c|c|}
\hline \multicolumn{2}{|c|}{ Properties } & Sum of Squares & df & $\begin{array}{c}\text { Mean } \\
\text { Square }\end{array}$ & $\mathbf{F}$ & Significance \\
\hline $\begin{array}{l}\text { Sand } \\
(\%)\end{array}$ & $\begin{array}{c}\text { Between Groups } \\
\text { Within Groups } \\
\text { Total } \\
\end{array}$ & $\begin{array}{c}16942.700 \\
3140.400 \\
20083.100 \\
\end{array}$ & $\begin{array}{c}2 \\
37 \\
39 \\
\end{array}$ & $\begin{array}{c}8471.350 \\
84.876\end{array}$ & 99.809 & 0.000 \\
\hline $\begin{array}{l}\text { Silt } \\
(\%)\end{array}$ & $\begin{array}{c}\text { Between Groups } \\
\text { Within Groups } \\
\text { Total }\end{array}$ & $\begin{array}{l}1469.283 \\
1786.892 \\
3256.175\end{array}$ & $\begin{array}{c}2 \\
37 \\
39\end{array}$ & $\begin{array}{l}734.642 \\
48.294\end{array}$ & 15.212 & 0.000 \\
\hline $\begin{array}{l}\text { Clay } \\
(\%)\end{array}$ & $\begin{array}{c}\text { Between Groups } \\
\text { Within Groups } \\
\text { Total }\end{array}$ & $\begin{array}{c}9410.563 \\
1840.412 \\
11250.975\end{array}$ & $\begin{array}{c}2 \\
37 \\
39\end{array}$ & $\begin{array}{c}4705.281 \\
49.741\end{array}$ & 94.596 & 0.000 \\
\hline $\begin{array}{l}\text { Bulk density } \\
(<2 \mathrm{~mm}, \mathrm{~g} / \mathrm{l})\end{array}$ & $\begin{array}{c}\text { Between Groups } \\
\text { Within Groups } \\
\text { Total }\end{array}$ & $\begin{array}{c}27981.618 \\
988749.182 \\
1016730.800\end{array}$ & $\begin{array}{c}2 \\
37 \\
39\end{array}$ & $\begin{array}{l}13990.809 \\
26722.951\end{array}$ & 0.524 & 0.597 \\
\hline $\mathrm{pH}$ & $\begin{array}{c}\text { Between Groups } \\
\text { Within Groups } \\
\text { Total } \\
\end{array}$ & $\begin{array}{l}36.149 \\
23.566 \\
59.715 \\
\end{array}$ & $\begin{array}{c}2 \\
37 \\
39 \\
\end{array}$ & $\begin{array}{l}18.075 \\
0.637\end{array}$ & 28.378 & 0.000 \\
\hline $\mathrm{EC}(\mu \mathrm{s} / \mathrm{cm})$ & $\begin{array}{c}\text { Between Groups } \\
\text { Within Groups } \\
\text { Total }\end{array}$ & $\begin{array}{l}1136475.122 \\
4045474.116 \\
5181949.238\end{array}$ & $\begin{array}{c}2 \\
37 \\
39\end{array}$ & $\begin{array}{l}568237.561 \\
109337.138\end{array}$ & 5.197 & 0.010 \\
\hline $\mathrm{C}(\%)$ & $\begin{array}{c}\text { Between Groups } \\
\text { Within Groups } \\
\text { Total }\end{array}$ & $\begin{array}{c}12.389 \\
4.204 \\
16.593\end{array}$ & $\begin{array}{c}2 \\
37 \\
39\end{array}$ & $\begin{array}{l}6.195 \\
0.114\end{array}$ & 54.524 & 0.000 \\
\hline $\mathrm{N}(\%)$ & $\begin{array}{c}\text { Between Groups } \\
\text { Within Groups } \\
\text { Total }\end{array}$ & $\begin{array}{l}0.103 \\
0.014 \\
0.117\end{array}$ & $\begin{array}{c}2 \\
37 \\
39\end{array}$ & $\begin{array}{l}0.051 \\
0.000\end{array}$ & 138.121 & 0.000 \\
\hline $\mathrm{C} / \mathrm{N}$ & $\begin{array}{l}\text { Between Groups } \\
\text { Within Groups }\end{array}$ & $\begin{array}{l}4470.592 \\
8790.676\end{array}$ & $\begin{array}{c}2 \\
37\end{array}$ & $\begin{array}{c}2235.296 \\
237.586\end{array}$ & 9.408 & 0.000 \\
\hline
\end{tabular}




\begin{tabular}{c|c|c|c|c|c|c} 
& Total & 13261.268 & 39 & & & \\
\hline & Between Groups & 3658.978 & 2 & 1829.489 & 39.573 & \\
$\mathrm{C}$ & Within Groups & 1710.535 & 37 & 46.231 & & 0.000 \\
(ton/ha) & Total & 5369.513 & 39 & & & \\
\hline \multirow{2}{*}{$\mathrm{N}$} & Between Groups & 31.323 & 2 & 15.661 & 122.891 & \\
(ton/ha) & Within Groups & 4.715 & 37 & 0.127 & & 0.000 \\
& Total & 36.038 & 39 & & & \\
\hline
\end{tabular}

